\title{
ハイフローテーターの紹介
}

構造及び操業結果

(䏭プラント建築設計研究所 宮 部 範 司

\section{"Hi-FLOTATOR" a new cyclone-type flotation cell designed for deinking, which has been developed by Shinhama Pump Mfg. Co., Ltd.}

\author{
Noriji Miyabe \\ Executive Director Plant Construction Design \& Research Co., Ltd.
}

Japan TAPPI gave praise to Mr. Morizane, the president of Shinhama Pump Mfg. Co., Ltd., who developed the new flotation cell which was based on his own idea.

The kneading process is used to improve the quality of deinked pulp by helping to release the ink particles from the surface of the fiber.

A certain portion of the ink particles are small in size. These small particles are difficult to remove by conventional flotation cells.

It has been proven in both pilot plant and commercial scale runs that the new type of flotation cell has excellent small particle removal efficiency.

This makes it possible to reduce the amount of wash water required and, to potentially reduce the size of the washer itself.

The new "Hi-FLOTATOR" has other advantages apart from excellent ink removal, these include clean operation, compact design, reduced maintenance and increased energy savings due to fewer motors and pumps.

To date, Nippon Paper group has installed 11 “Hi-FLOTATOR” plants in 8 mills. In this paper, I will show some comparisons between the "Hi-FLOTATOR" and other flotation cells thats are in operation in our mills.

\section{1. まえがき}

コスト節減のために始まったけ紙将生利用は今や世 界的な少资源・少エネルギーによる環境保護の観点と， ゴミの減昂化も念めたりサイクル運動によりノルマ化 されつつある。特に山本では世界に先がけ，1991 年 4 月に公们されたりサイクル法により，日本製紙連合会 が自主的な川槽として提げた’ 95 年度け紙利用率 55\% を一年繰りトけげることが川標とされている（平成 6 年 度 55\%)。DIP 配令摔のアップに伴い当然脱墨率の向 、施要求される。䛤米夕イプのフローテーターは滞留 時間や $\mathrm{G} / \mathrm{L}$ を大きくして性能を良くする傾向にあり， 大型月つエネルギー多消費型になって来ている。特に

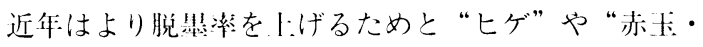

青玉”を無くするためにニーディングによりインクの 微粒子化・分散化を計る傾向にあり, 従来は洗浄分野 とされていた数 $\mu$ 以下の微小なインク片までもフ ローテーターによって除去することが必要となって来 な。

本稿で紹介するハイフローテーターは姝新浜ポンプ 製作所の独自の開発によるもので種々の試行錯誤を経 て完成され, 平成 5 年度の佐々木賞を受賞されたフ ローテーターである。数 $\mu$ から $200 \mu$ 以上までのイン ク片・㯖料類及び微細な軽量異物・粘着物等が高性能 に除去でき, 滞留時間が 2 3 分と極めて短く, G/L は 4 8/8セルと比較的少ない。コンパクトな密閉型サイ クロンであるため, 従来のフローテーターの污いイ メージを一掃し清潔で作業環境が良いほか, 稼動部が 
ないためメインテナンスフリーであり操業も極めて安 定している，またポンプ以外の動力は不要であるため, 電力原単位が少なく省工ネ的であるが, 他方, 処理濃 度が高くなると繊維ロスが多くなる傾向があり，低目 の濃度で運転するか 2 次フローテーターの強化が必要 である。

日本製紙(制釧路工場では'86 年に既設ラインの補完 用に開発当初の HIF-10 型の第 1 号機を採用した。イ ンク除去摔は平均的には満足の行くものであったが, 変動幅も大きく，良い時は極めて高効率であったため, 高位安定が出来れば素晴らしいフローテーターになる と予測されたので, 透明なサイクロンにより旋回流の 調整が出来る様にすることを前提に, '8 8 年に石巻工場 に新型の HIF-20 型の第 1 号機を採用した。その結果 が良好であったので，日本製紙 Gでは合計 11 プラン トにハイフローテーターを採用している。本来ならば 本紹介記事は侏新浜ポンプ製作所殿が行うべきかと思 われるが，上記経過もあり，また操業デー夕一を盛り 込んだ内容にとの要望であったので先越ではあるがお 引き受けすることにした。

古紙によって脱墨性が大幅に変動すること，及びパ ルパーの種類, ニーディングやソーキングの有無・滞 留時間或いは晒薬品・脱墨剤の種類や添加率等により 脱墨性が変わるため, フローテーターの性能比較は極 めて困難であるが，たまたま釧路工場や石巻工場で同 一系統にハイフローと他機種のフローテーターを使用 しているので，それらの比較からハイフローの性能を 調查した結果を紹介する。またその解析の中から使用 方法の反省等も含め言及してみた。

\section{2. 開発初期のハイフロー及び旧型ハイフロー}

図 1 は開発初期のハイフローの断面図である。サイ クロンシリンダーの上部に搭載したヘッダーから原料 がエジェクターで外気を吸引してサイクロンに入り， 遠心分離された空気が上部よりフロスを排出し，下部 よりアクセプトが排出される。サイクロン下部の固定 のエルトリエーターによってフロスの分離は助長され る。図 2 は旧夕イプハイフローの系統図である。原料 インレットヘッダー及び複数のエジェクターノズルを 装備したノズルケースがサイクロンシリンダーに直結 され，下部のエルトリエーターがお椀型に改善されて いる。

釧路工場ではDIPの増産に伴うフローテーターの 能力増強のためにこの旧タイプ HIF-10 型を採用した。 その操業データーを図 3 に示す。 A, B 社のフローテー ターをシリーズに用いて処理していた中間に HIF-10

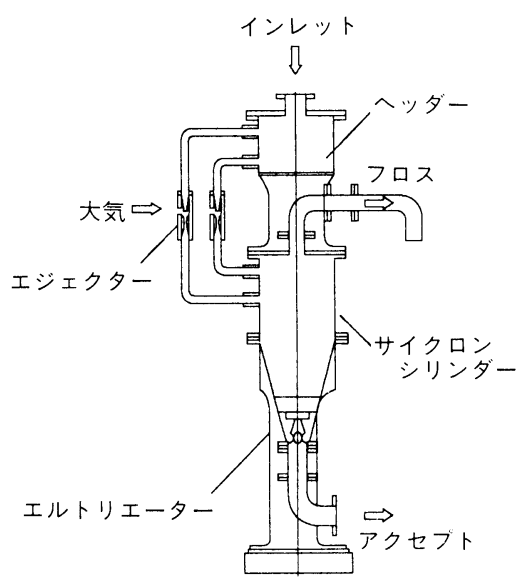

図 1 開発初期フローテーター

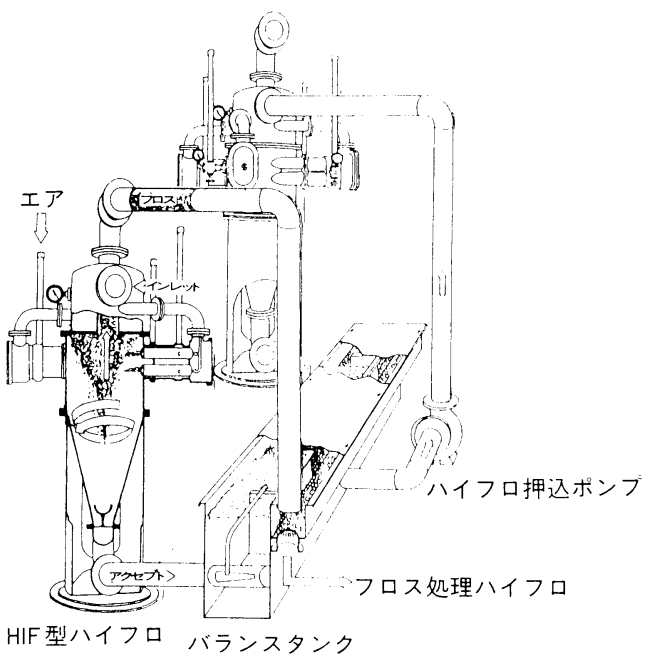

図 2 แ多イプハイフロー系統网

型 2 七ル $\times 2$ 段処理を追加した場合の, 1 セル当りのイ ンクカット率 (点線) は処理濃度 $1.0 \%$ で 7\% 16\% と, 石巻丁場の新聞古紙を使用したパイロットテスト 結果（実線）よりも2 3\%良い結果であった。

また・印は $\mathrm{H}_{2} \mathrm{O}_{2}$ 添加摔 $0.1 \%$,・印は $0.3 \%$ 添加時 の実機でのテストの結果であり, インクカット率は相 当大幅に変動している。・椡の内 8 梷は, 追加設置し た図 4 に示すフロスガイド在調整した時のデーターで あるが，その結果は図５に亦す様にフロスガイド位置 $200 \mathrm{~mm}$ の時を除けば, 他の要闪の変動範阙内であり 効果が判明しなかった。フロスガイド位管 $200 \mathrm{~mm} の$ 2 つのデーターを除く 6 吕の㣿咕. (1 セル処理) 表 1 に示した。 


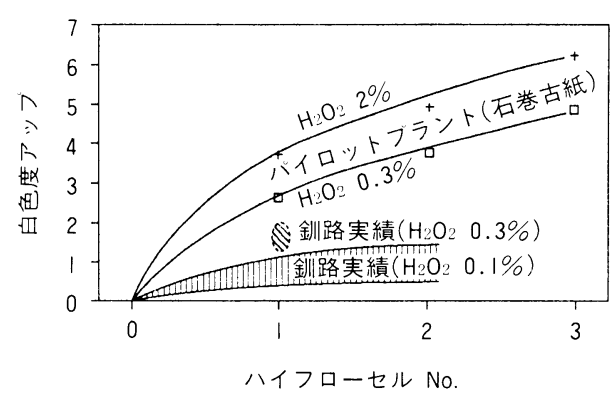

図 3.1 ハイフローでの主色度アップ

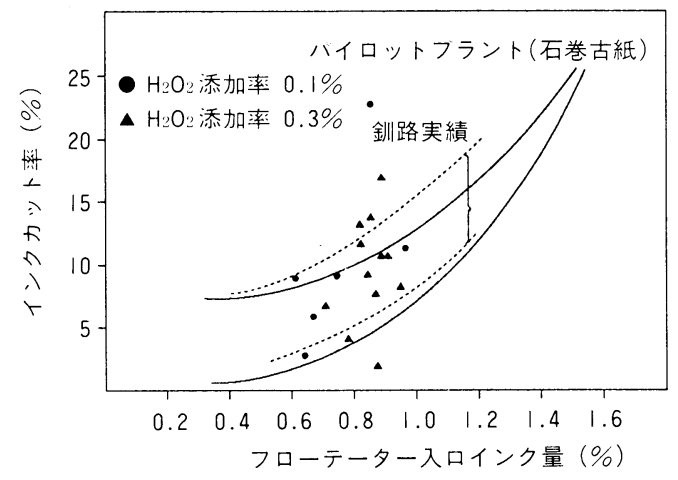

図 3.2 ハイフローテーター入口インク量とインク カット澵（1 セル当たり）

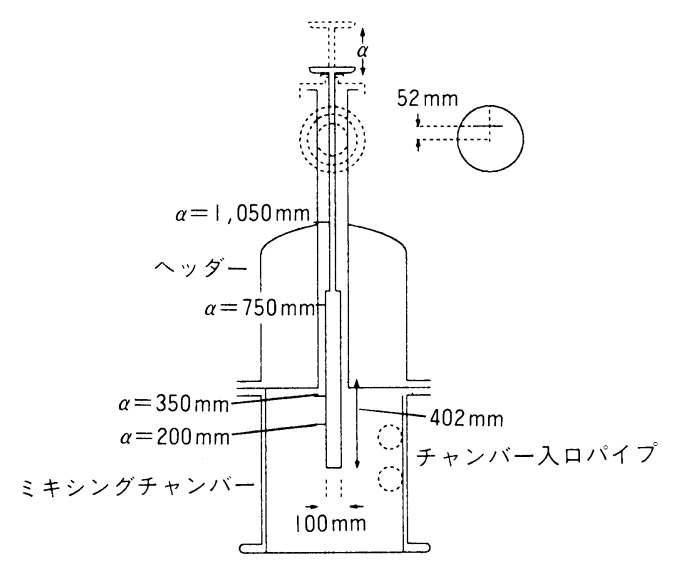

図4フロスガイドの位置

フロスのけ色度は $17.7 \%$ と低く灭は $28.1 \%$ であ るが，ふるい分紬成の $150 \mathrm{~m} / \mathrm{s}$ パスは $80.3 \%$ と高く, フリーネスは $98 \mathrm{cc}$ と低い。またフロス発生量は $1.38 \%$ でインク㽢のカット摔は $8.8 \%$ であるが，ルー ゼックスによる罪湖数のカット率は $19.8 \%$, 面積カッ

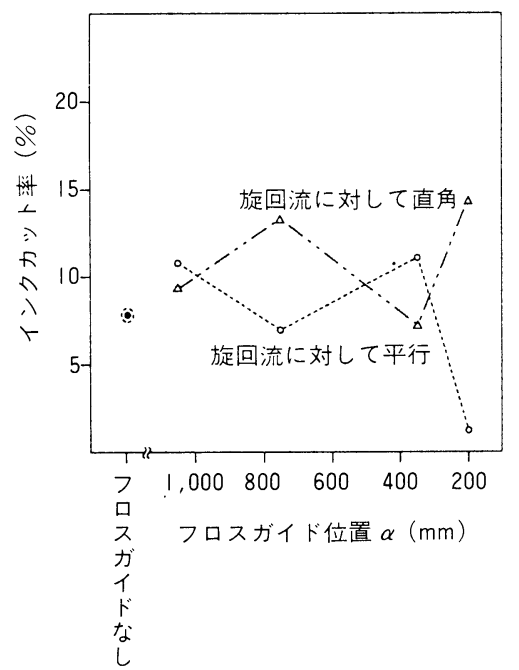

図 5.1 フロスガイド位置とインクカット率

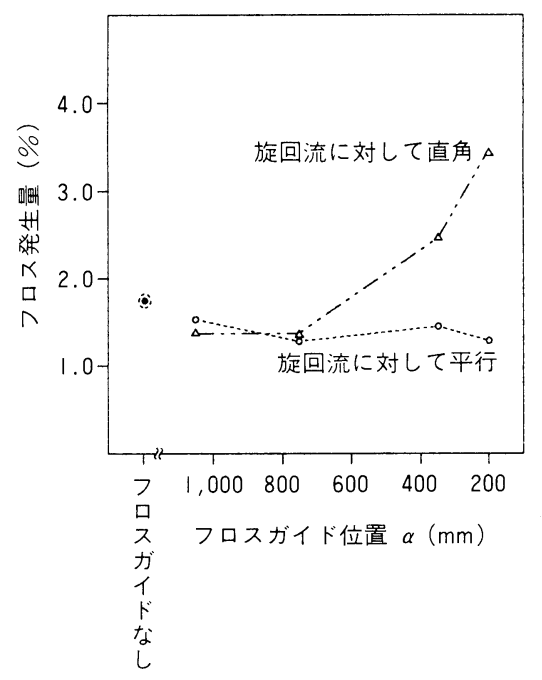

図 5.2 フロスガイド位置とフロス発生量

ト率は $25.2 \%$ であり白色度は $1.6 \%$ 上昇している。通 常は 8 セル処理であるため単純計算ではインク量の カット率は $50 \%$ 以上，インク個数カット率 $80 \%$ 以上, 面積カッ卜率 $90 \%$ 程度が期待出来た。前述の様な大幅 な変動が心配であったが，インジェクターによる空気 の吸引及びサイクロン下部のエルトリエーターの調整 により，フロスの発泡がコントロール出来れば画期的 なフローテーターになるものと予想された。そこでイ ンジェクターの性能アップと透明サイクロンによるフ ロス調整装置の開発を条件として, 石卷工場 N-DIP のフローテーター150 T/日及び $200 \mathrm{~T} /$ 日 2 系列のう 
表 1 ハイフロー婳り調查結果

\begin{tabular}{|c|c|c|c|c|c|c|c|c|c|c|c|c|c|c|c|c|c|}
\hline \multirow[b]{2}{*}{ サンプリング筒所 } & \multirow[b]{2}{*}{$\begin{array}{l}\text { パ } \\
\text { ル } \\
\text { プ } \\
\text { 濃 } \\
\text { 度 }\end{array}$} & \multirow[b]{2}{*}{$\begin{array}{l}7 \\
11 \\
1 \\
\text { 衣 } \\
x\end{array}$} & \multirow[b]{2}{*}{$\begin{array}{l}\text { 灰 } \\
\text { 分 }\end{array}$} & \multicolumn{4}{|c|}{ 白色度及び色相 } & \multicolumn{5}{|c|}{ ふるい分組成 } & \multicolumn{3}{|c|}{ ルーゼックス粼早 } & \multirow[b]{2}{*}{$\begin{array}{l}1 \\
ン \\
ク \\
⿱ 1 \\
\text { 量 }\end{array}$} & \multirow{2}{*}{$\begin{array}{l}7 \\
\text { 口 } \\
\text { 줄 } \\
\text { 発 } \\
\text { 生: } \\
\text { I: }\end{array}$} \\
\hline & & & & $\begin{array}{l}\text { 㒶 } \\
\text { 度 }\end{array}$ & $\mathrm{L}$ & a & b & $\begin{array}{c}24 \\
\text { Mesh } \\
\text { on }\end{array}$ & $\begin{array}{c}42 \\
\text { Mesh } \\
\text { on }\end{array}$ & $\begin{array}{c}80 \\
\text { Mesh } \\
\text { on }\end{array}$ & $\begin{array}{c}150 \\
\text { Mesh } \\
\text { on }\end{array}$ & $\begin{array}{c}150 \\
\text { Mesh } \\
\text { pass }\end{array}$ & 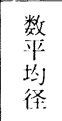 & $\begin{array}{l}\text { 湖 } \\
\text { 数 }\end{array}$ & $\begin{array}{l}\text { 面 } \\
\text { 秥 }\end{array}$ & & \\
\hline & $\%$ & $\mathrm{~m} l$ & $\%$ & $\%$ & $\%$ & - & - & $\%$ & $\%$ & $\%$ & $\%$ & $\%$ & $\mu$ & \multicolumn{2}{|c|}{10 湖 $/ \mathrm{g} \mathrm{cm}^{2} / \mathrm{g}$} & $\%$ & $\%$ \\
\hline 1 次ハイフロー入曰 & 0.95 & 158 & 9.0 & 45.9 & 71.4 & 0.18 & 5.1 & 29.8 & 12.9 & 15.0 & 8.2 & 34.3 & 8.0 & 29.3 & 26.8 & 0.83 & \\
\hline 1 次ハイフロー出口 & 0.96 & 153 & 8.7 & 47.5 & 72.8 & 0.17 & 5.3 & 29.7 & 13.0 & 15.1 & 8.2 & 33.9 & 7.6 & 23.5 & 20.0 & 0.76 & \\
\hline 1 次ハイフローフロス & 1.18 & 98 & 28.1 & 17.7 & 41.9 & -0.47 & -0.15 & 4.4 & 4.2 & 6.8 & 4.3 & 80.3 & & \multicolumn{3}{|c|}{ カット倠 $(\%)$} & \\
\hline 備考（フロス/入口） & 1.22 & $1 / 1.6$ & 3.1 & $1 / 2.6$ & $1 / 1.7$ & & & $1 / 6.8$ & $1 / 3.1$ & $1 / 2.2$ & $1 / 1.9$ & 2.3 & & 19.8 & 25.2 & 8.8 & 1.38 \\
\hline
\end{tabular}

ち, LWC 用に使用する唒 N-DIP $200 \mathrm{~T} /$ 日系に第 1 号 機の HIF-20 型を採用することにした。LWC 用に採 用したのはインクカット量の多い時のサンプルに軽量 異物・粘着物が少なかったことに魅力を感じたためで あった。

\section{3. 石巻工場に採用した HIF-20 型ハイフロー}

\section{(1) HIF 型ハイフローの改善}

図 6 に HIF 型ハイフローの断面図を示す。

原料入口ヘッダーサイクロンコーン部に架台兼用で 取りつけ，サイクロン上部には吸気へッダーを，また 空気の真空度制御用の CV を取りつけてある。

コーン下部にボルテックスフロー調整装置を取りつ け，フロス出口弁との調整と合わせ内压コントロール とフロス量の調整が出来る様になった。

\section{(2) インジェクターの改善}

図 7 にインジェクターの性能を示すが, 従来型ノズ ルと比較して新型ノズルは高真空では大差ないが，低 真空では 2 倍以上の $\mathrm{G} / \mathrm{L}$ が可能となった。この新型ノ ズルとボルテックスフロー調整装置の開発により, 表

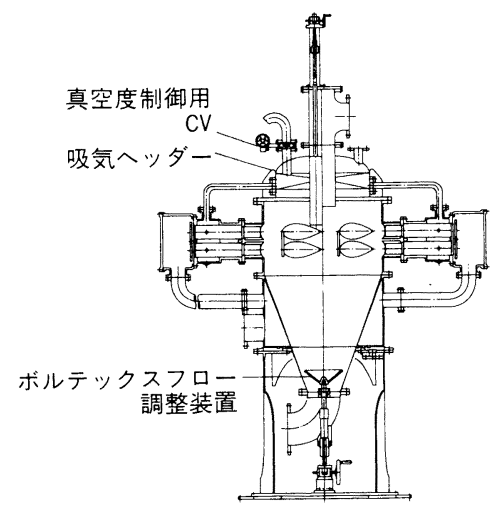

図 6 HIF 型ハイフロー断面図

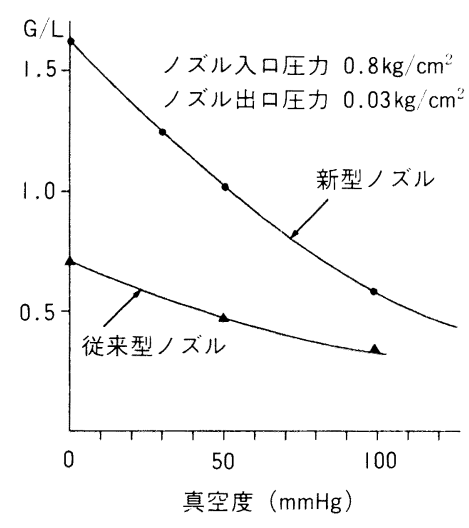

図７インジェクターノズルの性能

2 に示守様に同一のノズル入川库力 $\mathrm{P}_{1}$, 原料流量 $\mathrm{Q}_{1}$ でサイクロン内压 $\mathrm{P}_{2}, \mathrm{P}_{3}, \mathrm{P}_{4}$ を 0.05 0.08 kg/ $\mathrm{cm}^{2}$ 卜 げることが出来，G/L は闹一真空度で 33〜 77\%增加し ている。このため，间一条件でサイクロン内部での噴 流速度は14 16\%アップしサイクロン效果が墫強さ れた。

（3）石巻工場フローテーターの比較

表 3 に石巻工場 N-DIP の未眖用フローテーターと 晒用ハイフローの性能比較を示した。この両フロー

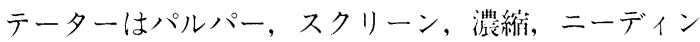
グ，ソーキングまで全く闹一ラインであるが，図８に 示す様に 2 次フローテーターの问收原料を末唒用入 ローテーターに回收しているため，未晒用フローテー ターの入口原料の角度が約 0.5 ポイント低く, イン ク量が約 $0.6 \%$ 多いのみである。人川インク量とイン クカット量を図 9 に示した。

図 9.3 に見る如く両者ほぼ闬一性能であるが, 図 9.1，9.2を比較すると相令係数は八イフローテーター の方が大きより安定していることが分かる。 $\mathrm{x}$ 軸の 切片が小さいことはハイフローの坊がより微小のイン 
表 2 真空度及び各部の圧力並びに $\mathrm{G} / \mathrm{L}$
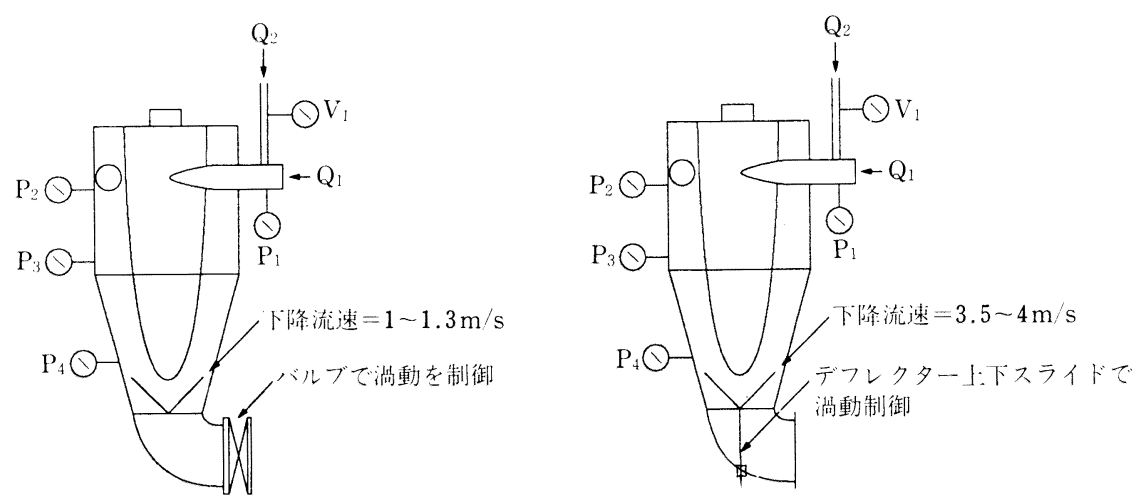

従来方式

\begin{tabular}{c|c|c|c|c|c|c|c|c}
\hline $\begin{array}{c}\mathrm{V}_{1} \\
(\mathrm{mmHg})\end{array}$ & $\begin{array}{c}\mathrm{P}_{1} \\
\left(\mathrm{~kg} / \mathrm{cm}^{2}\right)\end{array}$ & $\begin{array}{c}\mathrm{P}_{2} \\
\left(\mathrm{~kg} / \mathrm{cm}^{2}\right)\end{array}$ & $\begin{array}{c}\mathrm{P}_{3} \\
\left(\mathrm{~kg} / \mathrm{cm}^{2}\right)\end{array}$ & $\begin{array}{c}\mathrm{P}_{4} \\
\left(\mathrm{~kg} / \mathrm{cm}^{2}\right)\end{array}$ & $\begin{array}{c}\mathrm{Q}_{1} \\
(\mathrm{~L} / \mathrm{min})\end{array}$ & $\begin{array}{c}\mathrm{Q}_{2} \\
(\mathrm{NL} / \mathrm{min})\end{array}$ & $\begin{array}{c}\text { 噴流速度 } \\
(\mathrm{m} / \mathrm{s})\end{array}$ & $\begin{array}{c}\mathrm{G} / \mathrm{L} \\
0\end{array}$ \\
\hline 0.8 & 0.14 & 0.14 & 0.18 & 154 & 70 & 1.39 & 0.45 \\
\hline 50 & 0.8 & 0.12 & 0.12 & 0.16 & 155 & 47 & 1.19 & 0.30 \\
\hline 100 & 0.8 & 0.11 & 0.11 & 0.15 & 156 & 37 & 1.14 & 0.24 \\
\hline
\end{tabular}

新

\begin{tabular}{c|c|c|c|c|c|c|c|c}
\hline $\begin{array}{c}\mathrm{V}_{1} \\
(\mathrm{mmHg})\end{array}$ & $\begin{array}{c}\mathrm{P}_{1} \\
\left(\mathrm{~kg} / \mathrm{cm}^{2}\right)\end{array}$ & $\begin{array}{c}\mathrm{P}_{2} \\
\left(\mathrm{~kg} / \mathrm{cm}^{2}\right)\end{array}$ & $\begin{array}{c}\mathrm{P}_{3} \\
\left(\mathrm{~kg} / \mathrm{cm}^{2}\right)\end{array}$ & $\begin{array}{c}\mathrm{P}_{4} \\
\left(\mathrm{~kg} / \mathrm{cm}^{2}\right)\end{array}$ & $\begin{array}{c}\mathrm{Q}_{1} \\
(\mathrm{~L} / \mathrm{min})\end{array}$ & $\begin{array}{c}\mathrm{Q}_{2} \\
(\mathrm{NL} / \mathrm{min})\end{array}$ & $\begin{array}{c}\text { 噴流速度 } \\
(\mathrm{m} / \mathrm{s})\end{array}$ & $\begin{array}{c}\mathrm{G} / \mathrm{L} \\
0\end{array}$ \\
\hline 0.8 & 0.09 & 0.11 & 0.12 & 151 & 93 & 1.44 & 0.62 \\
\hline 50 & 0.8 & 0.07 & 0.08 & 0.10 & 153 & 81 & 1.38 & 0.53 \\
\hline 100 & 0.8 & 0.03 & 0.05 & 0.07 & 158 & 62 & 1.30 & 0.39 \\
\hline
\end{tabular}

ク片まで取れることをホしているものと思われる。

なお，図10は釧路. I場に採用した旧夕イプの HIF10 型1 セル処理での入川インク量とインクカット量 の関係であるが, 相軿係数は 0.42 であり,バラッキが 大きく $\mathrm{x}$ 軸切片も杫めて大きかったが，インジェク ターノズルの新型化とボルテックスフロー調整装置の 開発により，サイクロン効果が高位安定し相関係数は 0.946 となっている。

\section{(4) インク粒径別のインクカット率}

表 4 及び図 11 にインク粒径別のインクカット率を 示す。初期のハイフローと A, C, D 3 社のフローテー ターの比較から明らかな様に, $10 \mu$ 以下のインクの カット率には相当の差がありハイフローが優れている。 な捚 11 に現在のハイフローのパイロットプラン トによる米目の低質、質计紙 (Super Mixed
Officewaste) の粒径別カット率を並記したが，他社フ ローテーターに比して $200 \mu$ を越える粒径のインクま で相当に高いインク除去率となっている。表 5 は元 データーで米国 B. C. 社による測定值である。インク が除去し易い上質古紙とはいえ, $10 \mu$ 以上のインクの カット率は個数で 93 98\%,インク量で 95〜98\%と良 好である。

前述した様に今後更にDIP の配合率を、トげるため には，ニーディングが必要不可欠になると思われるが, その際のフローテーターとしてはハイフローが適して いると思われる。

\section{(5) $\mathbf{H}_{2} \mathbf{O}_{2}$ 添加の影響}

石巻工場では低白色度のパルプが少ないために末晒 N-DIPの白色度は50 程度と低目にする必要がある。 このため夏場の一時期を除いては $\mathrm{H}_{2} \mathrm{O}_{2}$ の添加はして 


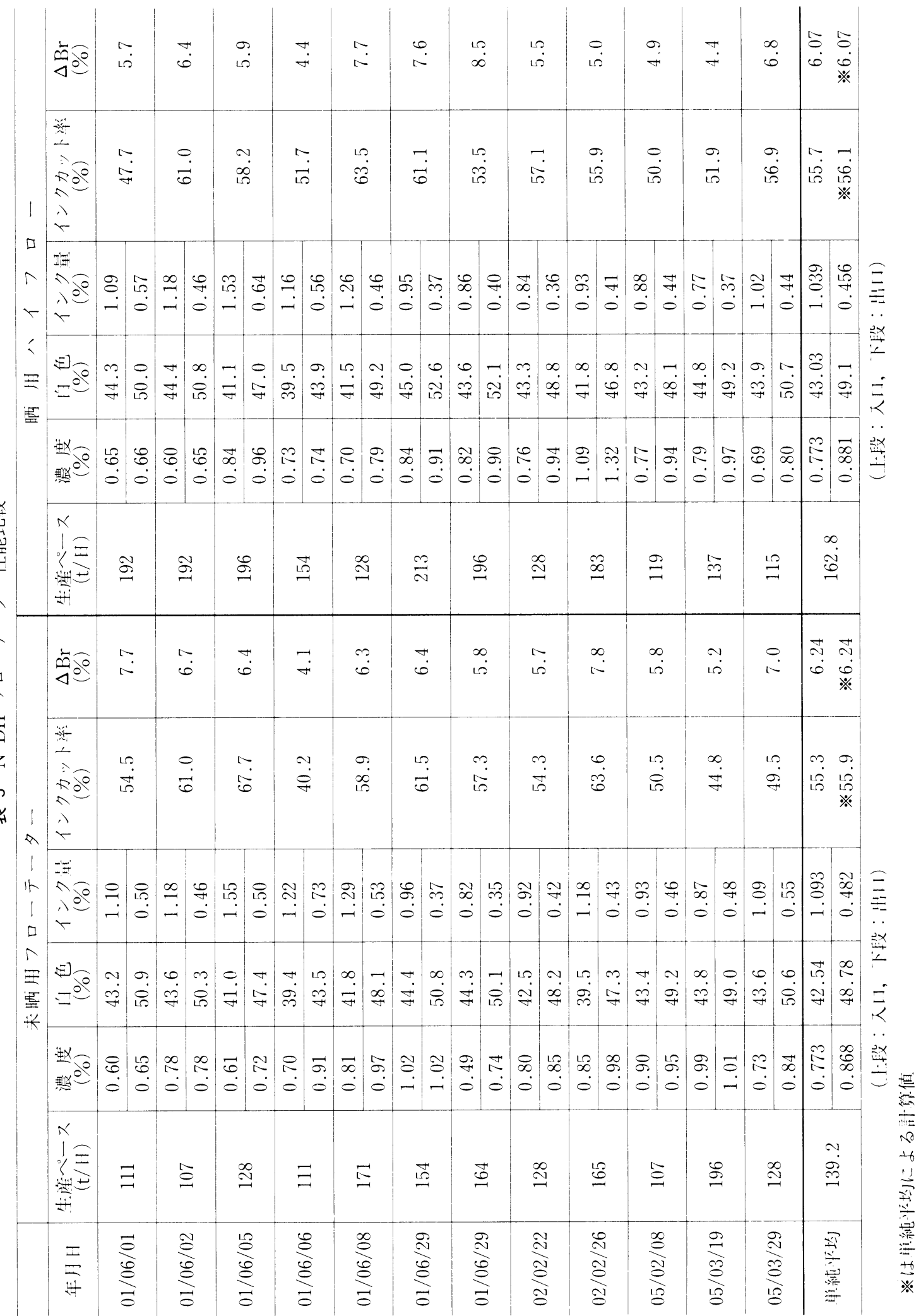




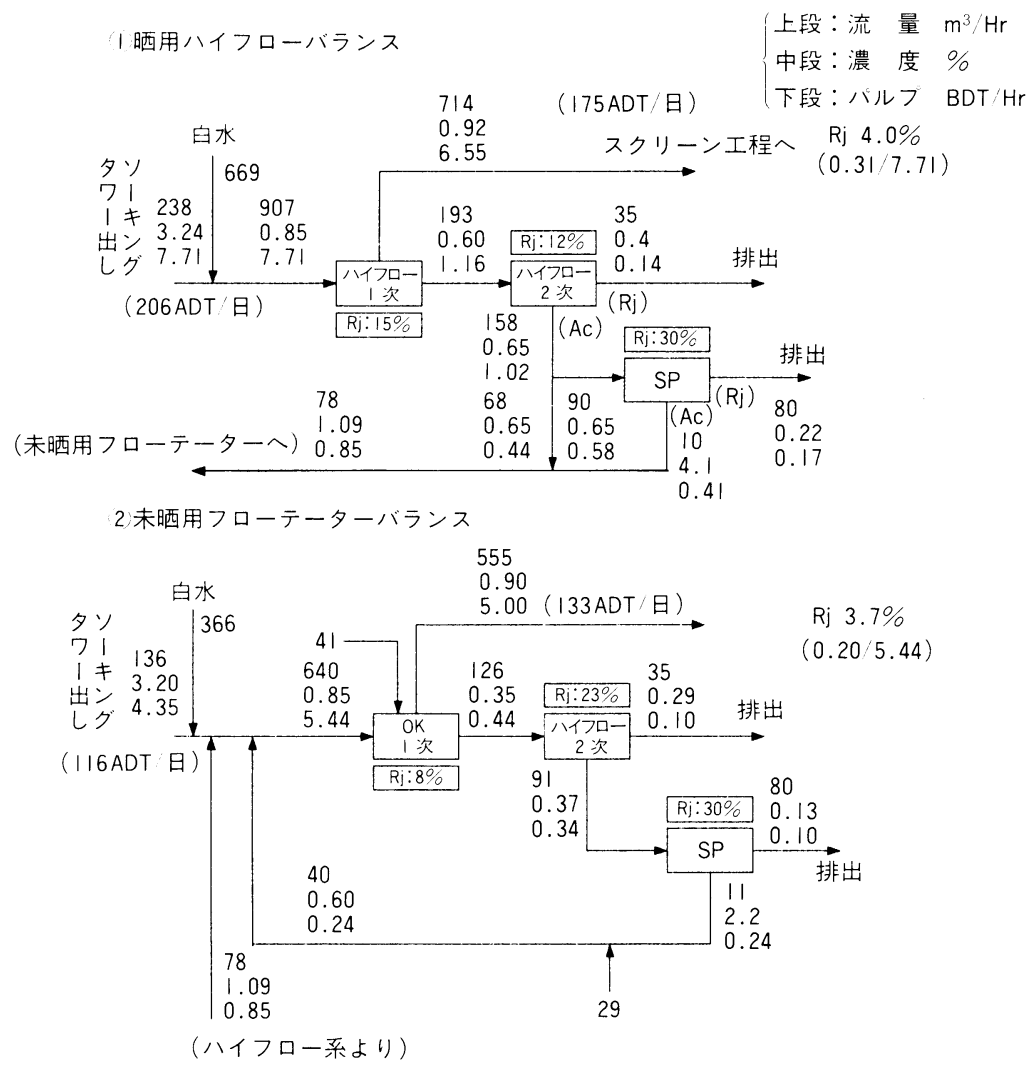

図 8 フローテーターのフローバランス

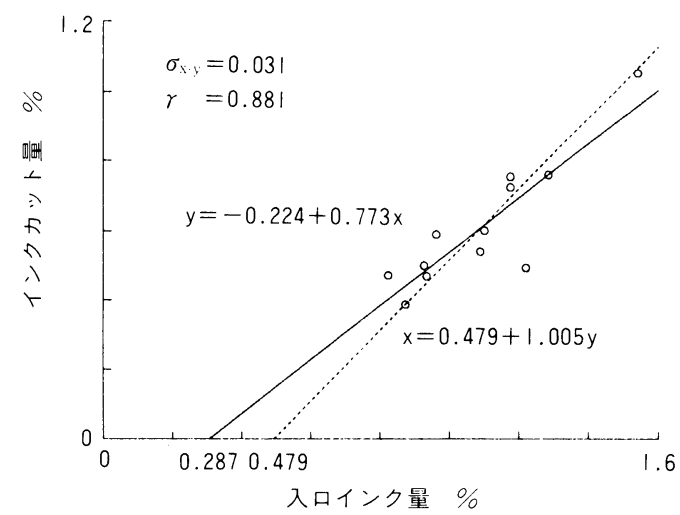

図 9.1 人川インク㱔とインクカット量(不卷「場 $\mathrm{N}$ DIP 栦悩川フローテーター)

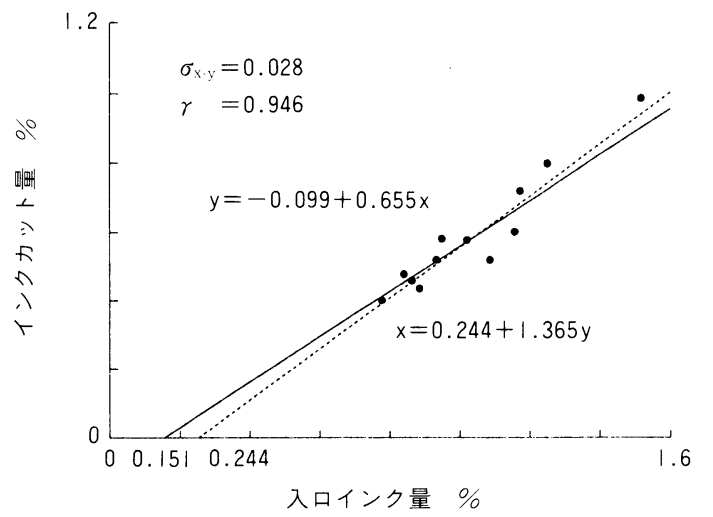

図 9.2 入ロインク量とインクカット量(石卷 [L埸 $\mathrm{N}-$ DIP 唒用ハイフロー)
いないが, 表 6 の様に0.1 0.2\%の添加で白色度は $2 \%$ 程度卜多ししインクのカット摔も約 $5 \%$ 上:茾してい る。

1994 作 2 月

\section{(6) 電力原単位}

フローテーション用の電力原単位は除塵やニーディ ングに比して少ないが，木晒用フローテーターとハイ

フローとでは約 15\%ハイフローが少ない。 


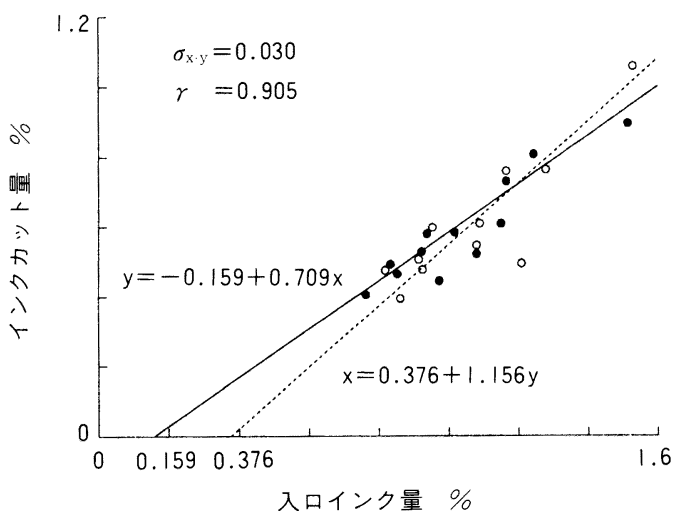

図 9.3 入口インク量とインクカット量

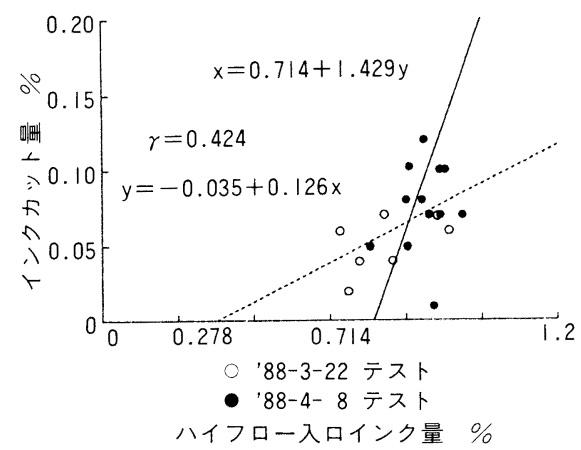

図 10 入口インク量とインクカット量 (ハイフロー 1 セル処理)

\section{(7) 各種フローテーターの比較}

図 12.1 に各種フローテーターでのインク星変化を 示す。

前処理の力法及び $\mathrm{H}_{2} \mathrm{O}_{2}$ の添加亩によりインクカッ 卜量は大幅に変化するため単純な比䡆は出来ないが, 八イフロー及び不巻の末朋用フローテーターが高性能 であることが明らかである。

表 4 ルーゼックスによる粘烽別力ット (DI-600の時)

\begin{tabular}{|c|c|c|c|c|c|}
\hline & \multicolumn{5}{|c|}{ 粒径別侗数 $\left(\times 10^{4}\right.$ 㑬 $\left./ \mathrm{g}\right)$} \\
\hline & $\widetilde{4 \mu}$ & $\begin{array}{l}4 \sim \\
8 \mu\end{array}$ & $\begin{array}{l}8 \sim \\
12 \mu\end{array}$ & $\begin{array}{l}12 \sim \\
16 \mu\end{array}$ & $\begin{array}{l}16 \sim \\
20 \mu\end{array}$ \\
\hline ハイフロー入口 & 2,160 & 1,155 & 538 & 140 & 52 \\
\hline 1 セル出口 & 1,080 & 562 & 272 & 101 & 38 \\
\hline 3 セル出口 & 577 & 301 & 210 & 16 & 21 \\
\hline 10 セル出山 & 222 & 118 & 15 & 30 & 15 \\
\hline 個数力ット率 $\eta$ & 89.7 & 89.8 & 97.2 & 78.6 & 71.2 \\
\hline $\mathrm{D}$ 社 $\mathrm{F} / \mathrm{T}$ 入川 & 1,203 & 636 & 342 & 140 & 112 \\
\hline $\mathrm{D}$ 社 $\mathrm{F} / \mathrm{T}$ 出曰 & 364 & 139 & 96 & 43 & 19 \\
\hline 個数カット率 $\eta$ & 69.7 & 78.1 & 71.9 & 69.3 & 83.0 \\
\hline $\mathrm{C}$ 社 $\mathrm{F} / \mathrm{T}$ 入门 & 1,676 & 958 & 435 & 152 & 112 \\
\hline $\mathrm{C}$ 社 F/T 出山 & 461 & 270 & 127 & 32 & 16 \\
\hline 個数力ツト率 $\eta$ & 72.5 & 71.8 & 70.8 & 78.9 & 85.7 \\
\hline $\mathrm{A}$ 社 $\mathrm{F} / \mathrm{T}$ 入山 & 1,259 & 597 & 305 & 140 & 112 \\
\hline $\mathrm{A}$ 社 $\mathrm{F} / \mathrm{T}$ 出口 & 460 & 176 & 90 & 36 & 18 \\
\hline 個数力ット摔 $\eta$ & 63.5 & 70.5 & 70.5 & 74.3 & 83.9 \\
\hline
\end{tabular}

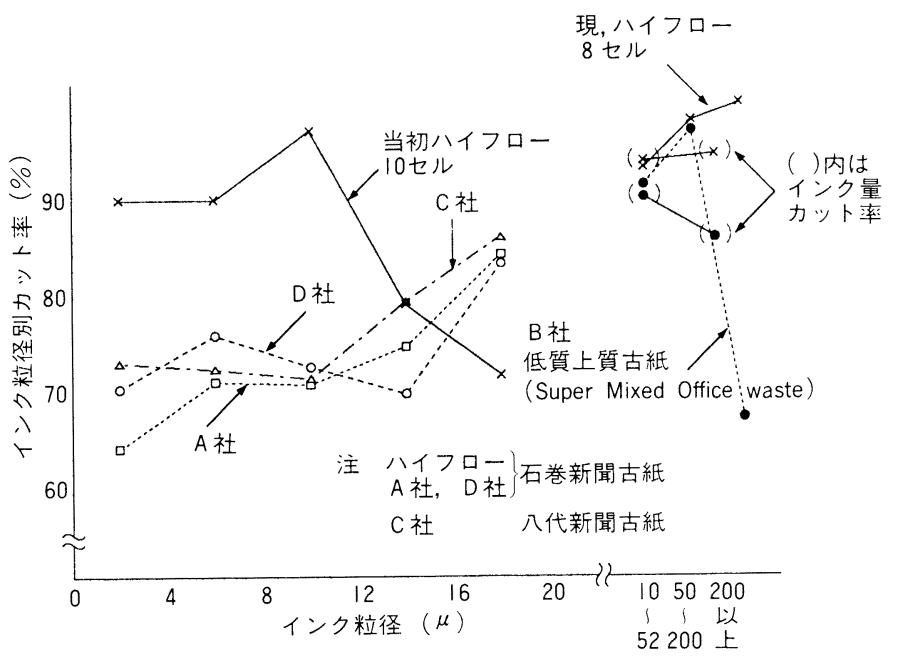

図 11 インク粒径別カット摔 
表 5 米国 B.C. 社の測定值

\begin{tabular}{|c|c|c|c|c|c|c|c|c|}
\hline \multicolumn{9}{|c|}{$\begin{array}{l}\text { DIRT COUNT-SHINHAMA } \\
\text { "FORT HOWARD PACK" TRIAL }\end{array}$} \\
\hline \multirow[t]{2}{*}{ SAMPLE } & \multicolumn{2}{|c|}{$\begin{array}{l}\text { SUB-VISIBLE } \\
(10-52 \text { micron })\end{array}$} & \multicolumn{2}{|c|}{$\begin{array}{c}\text { VISIBLE } \\
(50-200 \text { micron })\end{array}$} & \multicolumn{2}{|c|}{$\begin{array}{c}\text { TAPPI } \\
(200+\text { micron })\end{array}$} & \multicolumn{2}{|c|}{ TOTAL } \\
\hline & count & ppm & count & ppm & count & $\mathrm{ppm}$ & count & ppm \\
\hline Pulpet out & 2,448 & 3,154 & 152 & 3,660 & 9 & 7,629 & 2,610 & 14,443 \\
\hline Decker out & 1,708 & 2,444 & 109 & 3,359 & 2 & 532 & 1,821 & 6,334 \\
\hline$\# 1$ kneader out & 1,445 & 2,114 & 88 & 1,551 & - & - & 1,533 & 3,664 \\
\hline$\# 1 \mathrm{Hi}^{-}$con tower & 2,048 & 3,240 & 146 & 2,838 & 1 & 331 & 2,197 & 6,409 \\
\hline First Flotation & & & & & & & & \\
\hline $1 \mathrm{Hi}-\mathrm{Flo}$ in & 1,611 & 2,118 & 78 & 1,299 & - & - & 1,689 & 3,417 \\
\hline $1 \mathrm{Hi}-$ Flo out & 758 & 944 & 65 & 364 & - & - & 822 & 1,308 \\
\hline $2 \mathrm{Hi}-\mathrm{Flo}$ out & 782 & 958 & 24 & 455 & - & - & 806 & 1,413 \\
\hline $3 \mathrm{Hi}-\mathrm{Flo}$ out & 395 & 428 & 11 & 389 & 2 & 408 & 408 & 1,225 \\
\hline $4 \mathrm{Hi}-\mathrm{Flo}$ out & 337 & 351 & 8 & 241 & 1 & 158 & 346 & 750 \\
\hline $5 \mathrm{Hi}-\mathrm{Flo}$ out & 207 & 146 & 2 & 23 & 0 & 0 & 208 & 170 \\
\hline $6 \mathrm{Hi}-\mathrm{Flo}$ out & 220 & 211 & 6 & 99 & 0 & 0 & 226 & 310 \\
\hline $7 \mathrm{Hi}-$ Flo out & 193 & 171 & 5 & 67 & 0 & 0 & 197 & 237 \\
\hline $8 \mathrm{Hi}-\mathrm{Flo}$ out & 164 & 147 & 3 & 62 & 0 & 0 & 167 & 209 \\
\hline \#1 Washer & 93.3 & 95.3 & 98.0 & 98.3 & & & 93.6 & 98.6 \\
\hline
\end{tabular}

NOTE $:$ count $=\#$ particles per 100 square millimeters

表 $6 \mathrm{H}_{2} \mathrm{O}_{2}$ 添加の影響

\begin{tabular}{|c|c|c|c|c|c|c|c|}
\hline & \multicolumn{3}{|c|}{ 未晒用フローテーター } & \multicolumn{3}{|c|}{ 晒用八イフロー } \\
\hline & & 入口 & 出口 & 差カット率 & 入 口 & 出口 & 差カット率 \\
\hline \multirow{4}{*}{$\begin{array}{l}\mathrm{H}_{2} \mathrm{O}_{2} \\
\text { 添加 } \\
\text { せず }\end{array}$} & 度 \% & 0.99 & 1.01 & +0.02 & 0.79 & 0.97 & +0.18 \\
\hline & インク早 \% & 0.87 & 0.48 & 44.8 & 0.77 & 0.37 & 52.0 \\
\hline & 分 \% & 8.69 & 7.53 & 13.3 & 8.26 & 5.55 & 32.8 \\
\hline & 门色度\% & 43.8 & 49.0 & +5.2 & 44.8 & 49.2 & +4.4 \\
\hline \multirow{4}{*}{$\begin{array}{c}\mathrm{H}_{2} \mathrm{O}_{2} \\
0.15 \% \\
\text { 添/吅 }\end{array}$} & 濃 度 \% & 0.73 & 0.84 & +0.11 & 0.69 & 0.80 & +0.11 \\
\hline & インク曻 \% & 1.09 & 0.55 & 49.6 & 1.02 & 0.44 & 56.9 \\
\hline & 疢 分 \% & 8.24 & 6.72 & 18.5 & 9.75 & 6.69 & 31.4 \\
\hline & 白色度 \% & 43.6 & 50.6 & +7.0 & 43.9 & 50.7 & +6.8 \\
\hline
\end{tabular}

表 7 フローテーション用電力

\begin{tabular}{|c|c|c|c|}
\hline & & $\begin{array}{l}\text { 未 晒 用 } \\
\text { フローテーター }\end{array}$ & $\begin{array}{l}\text { 眖 用 } \\
\text { ハイフロー }\end{array}$ \\
\hline 設備照力/モーター台数 & $\mathrm{kW} /$ 台 & $624.5 / 17$ 台 & $446.3 / 14$ 台 \\
\hline 入力消費電力 & $\mathrm{kW}$ & 410 & 464 \\
\hline 完成原料日産 & $\mathrm{t} / \mathrm{\theta}$ & 150 & 200 \\
\hline 笔力原単位。 & $\mathrm{kWH} / \mathrm{t}$ & 65.5 & 55.7 \\
\hline
\end{tabular}


図 12.2 に各種フローテーターのフロスの比較を示 した。

機種及びフロス排出率によりフロス中の繊維の篩分 組成及び成分に大幅な差がある。しかもこれはスポッ トのデーターであり, フローテーターの処理濃度及び 脱墨片の種類により大幅な変動がある。表 8 に示す如 くハイフローのフロス灰分は通常は高い処理濃度を上 げるとフロス中の繊維組成が増加し灰分除去は悪くな り脱墨率も低下寸る。図 13 に示す様にハイフローでは 濃度が低目の方が白色度アップ及びインクカット量が

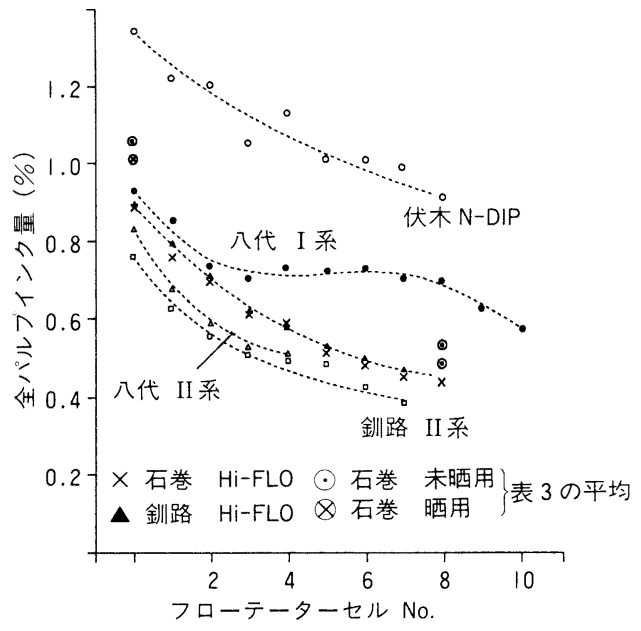

図 12.1 各種フローテーターの比較(インク量の変化)
高い傾向にあり，後述するフロスの䋊維:[叫仪と合わせ 検討を要するものと思われる。

表 8 ハイフローフロス中の㤋

\begin{tabular}{l|c|c|c}
\hline & 石卷士場 & 釧路士場 & 号払工場 \\
\hline 1 セルフロス & $19.3^{*}$ & 34.0 & 32.3 \\
2 セルフロス & 22.2 & - & 27.1 \\
3 セルフロス & 24.4 & 40.6 & 26.8 \\
5 セルフロス & - & 40.9 & - \\
8 セルフロス & 41.2 & 36.4 & 15.8 \\
\hline
\end{tabular}

${ }^{*}$ No.1 セル給液量が少ない時と思われる

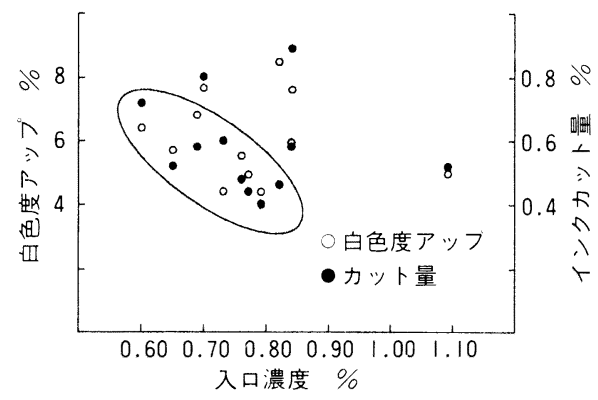

図 13 石巻 I場 眖用ハイフロー

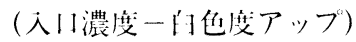
(入口濃度ーインクカット星)

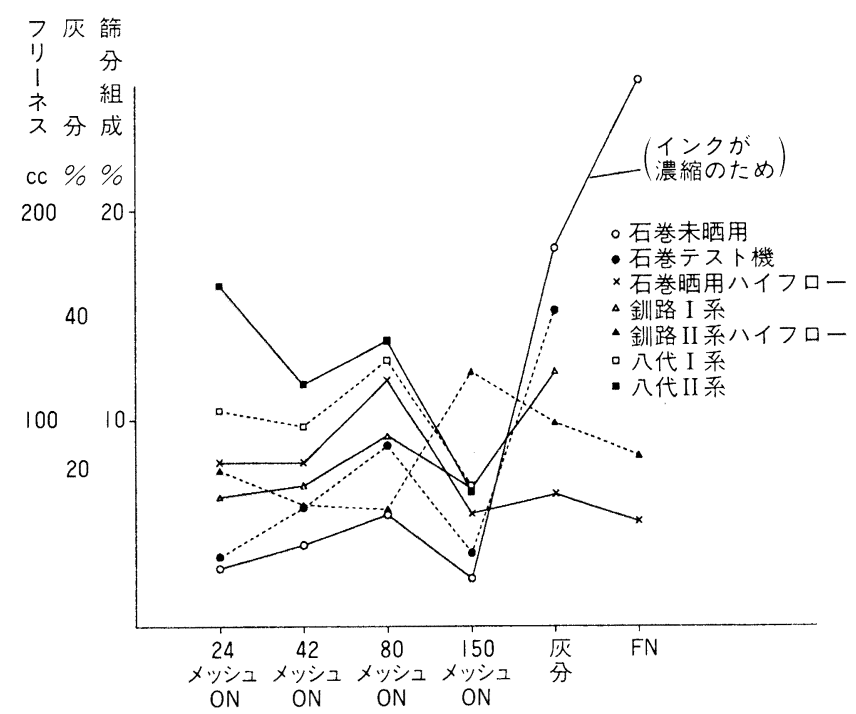

図 12.2 各種フローテーターのフロス比較 


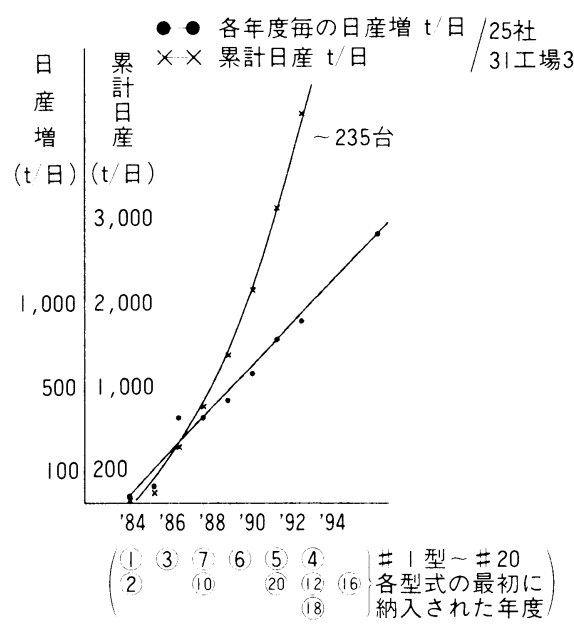

図 14 ハイフロー処理の DIP プラント

\section{4. ま と め}

種々記述した通り, HIF 型ハイフローは微細なイン ク片, 填料等の分離効果は良好で図 14 に示す様に納入 実績が急増しているが，今回本稿を書くに当って種々 に調査してみると, 不巻工場未晒用フローテーターと 石巻工場でテストした某社のフローテーターも微細な インク等のカット率及び電力原単位を除けば同レベル にある。世界的にみて全く独創性のあるフローテー ターを新浜ポンプ製作所株殿が独自に開発されたこと に対し敬意を表すると共に今後，更に下記 2 項を含め 改良を加えてょり性能向上を計られることを期待した )。

(1) フロスの回収

図 8 に示した様に晒用ハイフローと末晒用フロー
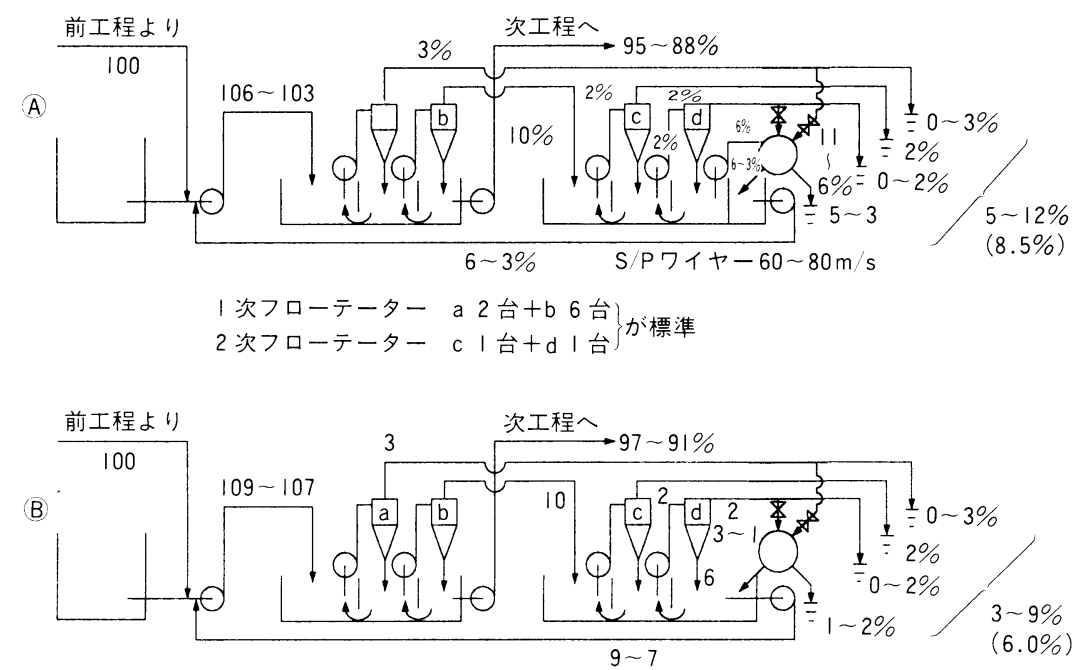

2 次フローテーター d | 台を 3〜4台に増加又は大型化し

$\mathrm{S} / \mathrm{P}$ フィルターのワイヤー $80 \sim 100 \mathrm{~m} / \mathrm{s}$

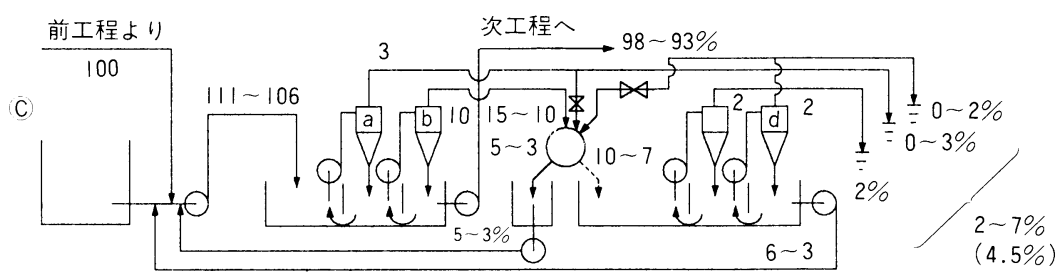

2 次フローテーター d I 台を 2 〜台に増加又は大型化し

$\mathrm{S} / \mathrm{P}$ フィルターワイヤーを $50 \sim 60 \mathrm{~m} / \mathrm{s}$ に変更

図 15 フロス処理のフローバランス 
テーターの纎維排出量は $4.0 \%$ と $3.6 \%$ で大差がない 様であるが，前述した様に晒用ハイフローのフロス回 収を未晒用フローテーターに回収しているためであり， 他士場の例では $10 \%$ 以上も廃棄している例もある。

図 15 のは現在のハイフローの標準的なフローで あり $10 \%$ 程度のフロス廃棄が必要であるが, ®のフ ローに変更しフロス処理を強化すれば $6 \%$ 程度に減少 出来る。また@のフローに変更すれば 4 5\%に減少で
きるものと思われる。

(2) サイクロン效果の向1:

サイクロンコーン部の解度は新浜ポンプ製作所殿の

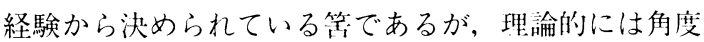
を小さくするとサイクロン効果が人きくなり，フロス の発生面積も增加するので効摔响、に然少するものと 思われる。 